\title{
CONTRATO ADMINISTRATIVO E A LEI DE ARBITRAGEM
}

\author{
Mauro Roberto Gomes de Mattos
}

I - O Inicio da Arbitragem no Brasil. II - A Lei n ${ }^{\circ}$ 9.307, de 23.09.96. III - O Contrato Administrativo e a Lei de Arbitragem. IIIa - Empresa Pública e a Sociedade de Economia Mista. IIIb - O Contrato de Concessão e a Lei de Arbitragem. IV — Vantagens da arbitragem e situações em que ela pode ser efetivada ou não. Conclusão.

\section{I - O Início da Arbitragem no Brasil}

A arbitragem é o meio extrajudicial que as partes de uma relação contratual podem utilizar para resolver conflitos de ordem patrimonial, envolvendo direitos disponíveis, que serão solucionados pelos árbitros, escolhidos pelos mesmos.

Apesar de pouco divulgada a arbitragem convive em nosso ordenamento desde os tempos da colonização portuguesa, figurando como norma obrigatória naquela época, sendo que a Constituição Imperial, expressamente, previa o Juízo Arbitral, no seu art. 160.

Seguindo essa tendência, o Código Comercial de 1850, que ainda é vigente, veio à tona com alguns artigos que estabeleciam o arbitramento como obrigatório, disso sendo exemplo, o seu artigo 294, que previa expressamente, e em caráter obrigatório que o juízo arbitral nas causas entre sócios e sociedades comerciais, durante a existência da sociedade ou companhia, sua liquidação ou partilha.

Diferentemente não dispunha o Regulamento 737, também de 1850 , que em seu artigo 411 exigia o Juízo Arbitral para a solução das causas comerciais.

Mais tarde, a Lei $n^{\circ} 1.350$, de 14/09/1866, revogou os dispositivos que privilegiavam a solução arbitral, criando um verdadeiro desuso sobre a aludida matéria.

Todavia, no Direito Internacional cada vez mais a arbitragem era aplicada, especialmente nos contratos de navegação, destoando da nossa realidade jurídica.

Assim, para não ferir o cenário internacional, o Brasil aderiu ao Protocolo de Genebra de 1923, incorporando e reconhecendo em seu ordenamento jurídico interno pelo Decreto $\mathrm{n}^{\circ} 21.187$, de 22 de março de 1932, a validade de compromissos ou 
cláusulas compromissórias, pelos quais os Estados (ou partes) se obrigam, contratualmente, em matéria comercial ou outra suscetível de ser resolvida mediante arbitragem, a submeter suas divergências ao juízo de árbitros, ainda que a arbitragem se verifique em um país de jurisdição diferente.

Igualmente, também o Brasil faz parte da "Convenção Interamericana sobre Arbitragem Comercial Internacional", assinada no Panamá em 1975, ratificada, e promulgada em solo nacional em 10/05/96.

Deixando de lado os Tratados Internacionais, é de se trazer à tona a nossa legislação interna, onde os Códigos de Processo Civil de 1939 e 1973 adotaram a possibilidade de solução de litígios pelo Juízo Arbitral.

$\mathrm{O}$ artigo $\mathrm{n}^{\circ} 1.072$, do Código de Processo Civil assim esta redigido:

"Art. 1.072 - As pessoas capazes de contratar poderão louvar-se, mediante compromisso escrito, em árbitros que lhes resolvam as pendências judiciais ou extrajudiciais de qualquer valor, concernentes a direitos patrimoniais, sobre os quais a lei admita a transação."

$\mathrm{Na}$ verdade, um dos grandes avanços da arbitragem, em nosso sistema jurídico foi a vinda da Lei n” 9.099/95, que ao dispor sobre os "Juizados Especiais Cíveis e Criminais", implantados por imposição constitucional (art. 98, I), nas causas sob a sua jurisdição, veio admitir o julgamento através de "juízo arbitral", com o árbitro escolhido pelas partes, podendo decidir por eqüidade (art. 25), sujeitando o laudo à homologação judicial por sentença irrecorrível (art. 26).

Também merece destaque o Protocolo de Brasília para a solução de controvérsias do MERCOSUL, firmado pelo Brasil, Argentina, Uruguai e Paraguai, que no seu capítulo IV reconhece o procedimento arbitral como o aplicável (art. $\left.8^{\circ}\right)^{1}$ para a solução de controvérsias entre os seus Estados-Partes (art. $7^{\circ}$ ).

Já sob o prisma Constitucional, a atual Carta erigiu como autêntico pressuposto processual, o arbitramento obrigatório ${ }^{2}$, ao estabelecer no seu art. $217, \S 1^{\circ}$ que: “O Poder Judiciário só admitirá ações relativas à disciplina e às competições desportivas após esgotarem-se as instâncias da justiça desportiva reguladas em lei. ${ }^{3 . *}$

E, por fim, sobreveio a Lei $\mathrm{n}^{\circ}$ 9.307, de 23.09.96, que alterou profundamente o instituto da arbitragem em nosso País ${ }^{4}$, e, por esta razão, será objeto de análise no próximo tópico, dada a sua envergadura para o atual cenário jurídico.

1 "Art. $8^{\circ}$ - Os Estados-partes declaram que reconhecem como obrigatório, ipso facto em sem necessidade de acordo especial, a jurisdição do tribunal arbitral que em cada caso se constitua para conhecer e resolver todas as controvérsias a que se refere o presente Protocolo.

2 Sálvio de Figueiredo Teixeira, "A Arbitragem no Sistema Jurídico Brasileiro", in " A Arbitragem na Era da Globalização", 2 ed., ed. Forense, 1999, p. 29.

3 Aprofundar em "Autonomia desportiva: conteúdo e limites", por Luís Roberto Barroso, in RDP 97/94.

4 Sálvio de Figueiredo, cit. ant., p. 29. 
A Lei $n^{\circ}$ 9.307/96 nasceu sob pesada crítica, eis que parte da doutrina entendia que ela seria inconstitucional, ao impedir que o Poder Judiciário apreciasse a questão resolvida por meio da arbitragem.

Não resta dúvida que este temor é sobremaneira exagerado, pois o Juízo Arbitral não exclui a apreciação do Poder Judiciário, que possui a soberania se acionado for, de rever ou anular decisões extrajudiciais que tenham sido tomadas com vícios de origem.

Aliás, esta é a redação do artigo 33 da respectiva lei, literis:

“Art. 33 - A parte interessada poderá pleitear ao órgão do Poder Judiciário competente a decretação da nulidade da sentença arbitral, nos casos previstos nesta lei.

Também poderá, segundo o estipulado no $\S 3^{\circ}$ do citado art. 33, a parte argüir decretação da nulidade da sentença arbitral mediante a apresentação de embargos de devedor, conforme o art. 741 e seguintes do CPC, se houver execução judicial.

No mesmo diapasão, e comprovando que a Lei de Arbitragem não padece do vício da inconstitucionalidade, o seu artigo 41 alterou a redação do inc. III do art. 584 do CPC e passou a considerar, a sentença arbitral como título executivo judicial, o que significa dizer que a sua execução definitiva estará condicionada ao Poder Judiciário.

Também a sentença arbitral estrangeira, para ser reconhecida ou executada no Brasil, deverá ser precedida da homologação pelo Supremo Tribunal Federal (art. 35).

Como visto, não há que se falar que a Lei $n^{\circ} 9.307 / 96$ fere o art. $5^{\circ}, \mathrm{XXXV}$ da $\mathrm{CF}$, eis que a acessibilidade ao Poder Judiciário não ficou comprometida por ela, pelo contrário, como a arbitragem é uma espécie de Justiça Privada, os seus laudos estarão sempre expostos a soberana ótica da jurisdição estatal.

Ultrapassada a questão da constitucionalidade da Lei sub examem, o seu artigo inaugural estipula que "as pessoas capazes de contratar poderão valer-se de arbitragem para dirimir litígios relativos a direitos patrimoniais disponíveis."

A arbitragem poderá ser de direito ou de equiidade (art. $2^{\circ}$ ), podendo as partes escolherem, livremente, as regras de direito que serão aplicadas na espécie $\left(\S 1^{\circ}\right.$ do art. $2^{\circ}$ ), bem como, que ela se realize com base nos princípios gerais de direito, nos usos e costumes e nas regras internacionais de comércio $\left(\S 2^{\circ}\right.$, do art. $\left.2^{\circ}\right)$.

A denominada cláusula compromissória, pacto prévio ou cláusula arbitral "é a convenção" preliminar "através de qual as partes em um contrato comprometem-se a submeter à arbitragem os litígios que possam vir a surgir, relativamente a tal contrato" (art. $4^{\circ}$ ).

Obrigatoriamente ela é escrita $\left(\S 1^{\circ}\right.$, do art. $\left.4^{\circ}\right)$ e os contratantes acordam em conferir aos árbitros a devida competência para a solução da controvérsia, resultante da execução do contrato. 
Qualquer pessoa capaz e que usufrua de confiança das partes interessadas poderá ser árbitro (art. 13), que no desempenho de sua função deverá proceder com imparcialidade, independência, competência, diligência e discrição ( $\$ 6^{\circ}$ do art. 13).

No exercício de suas funções ou em razão delas, os árbitros ficam equiparados aos funcionários públicos, para fins da legislação penal (art. 17) isto porque, o árbitro é considerado juiz de fato e de direito, sendo que a sentença colegiada não fica sujeita a recurso ou a homologação pelo Poder Judiciário (art. 18).

Considera-se instituída a arbitragem quando aceita a nomeação pelo árbitro (art. 19), obedecendo o procedimento estabelecido pelas partes na convenção de arbitragem, que poderá reportar-se às regras de um órgão arbitral institucional ou entidade especializada, facultando-se, ainda, às partes delegar ao próprio, ou ao tribunal arbitral, regular o procedimento (art. 21).

Os parágrafos do art.21 da Lei $n^{\circ} 9.307 / 96$, regula as seguintes hipóteses do procedimento arbitral :

“ $\S 1^{\circ}$ — Não havendo estipulação acerca do procedimento, caberá ao árbitro ou ao Tribunal discipliná-lo.

$\S 2^{\circ}$ - Serão, sempre, respeitados no procedimento arbitral os princípios da contraditório, da igualdade das partes, da imparcialidade do árbitro e de seu livre convencimento.

$\S 3^{\circ}$ - As partes poderão postular por intermédio de advogado, respeitada, sempre, a faculdade de designar quem as represente ou assista no procedimento arbitral.

$\S 4^{\circ}$ - Competirá ao árbitro ou ao tribunal arbitral, no início do procedimento, tentar a conciliação das partes, aplicando-se no que couber, o art. 28 desta Lei ."

No procedimento arbitral, caso sinta a necessidade poderá o árbitro ou o tribunal arbitral tomar o depoimento das partes, ouvir testemunhas e determinar a realização de perícias ou outras provas que julgar necessárias, mediante requerimento das partes ou de ofício (art. 22).

Após o percurso de todo o íter legal, será proferida a sentença arbitral, no prazo estipulado pelas partes, ou na sua falta, ela deverá ser confeccionado em seis meses, contados da instituição ou da substituição do árbitro (art. 23).

Todavia, caso a hipótese julgada seja complexa, as partes e os árbitros, de comum acordo, poderão prorrogar o prazo estipulado (parágrafo único, do art. 23).

Necessariamente a decisão do árbitro será expressa em documento escrito (art. 24), sendo que se forem vários os árbitros, a decisão será tomada por maioria, ou se não houver acordo majoritário, prevalecerá o voto do presidente do Tribunal Arbitral $\left(\S 1^{\circ}\right)$, sendo que na hipótese de voto divergente, poderá ser declarado em separado $\left(\S 2^{\circ}\right)$.

Importante destacar que, sobrevindo no curso da arbitragem controvérsia acerca de direitos indisponíveis e verificando-se que, de sua desistência, ou não, dependerá o julgamento, o árbitro ou o tribunal remeterá as partes à autoridade competente do Poder Judiciário, paralisando o procedimento arbitral (art. 25). Após a solução da 
questão prejudicial e juntada aos autos, a sentença ou acórdão transitado em julgado, terá normal seguimento a arbitragem.

$\mathrm{O}$ artigo 26 , elenca como obrigatórios da sentença arbitral os seguintes requisitos:

"I - o relatório, que conterá os nomes das partes e o resumo do litígio;

II - os fundamentos da decisão, onde serão analisadas as questões de fato e de direito, mencionando-se, expressamente, se os árbitro julgaram por equiidade;

III - o dispositivo, em que os árbitros resolverão as questões que lhe forem submetidas e estabelecerão o prazo para o cumprimento da decisão, se for o caso;

IV - a data e o lugar em que foi proferida."

Possui a sentença arbitral, como já dito alhures, efeitos de título executivo e será nula se contiver alguma das hipóteses contidas no art. 32, podendo ser pleiteada a competente decretação de nulidade perante ao Poder Judiciário (art. 33).

Esta é uma breve radiografia da Lei $n^{\circ}$ 9.307/96 que trouxe para o nosso cenário jurídico a arbitragem como uma forma mais célebre de solução de litígios, revelando-se ser mais uma opção segura para as partes contratantes.

Resta saber se a arbitragem poderá ser utilizada para a solução de conflitos entre particulares e entes públicos. A resposta a esta indagação vem a seguir, no próximo tópico.

\section{III - O Contrato Administrativo e a Lei de Arbitragem}

\section{IIla - Empresa Pública e a Sociedade de Economia Mista}

Enfrentaremos a questão pelo exame da situação menos complexa, eis que a empresa pública e a sociedade de economia mista possuem personalidade jurídica de direito privado 5 , o que facilita a nossa análise.

Visando torná-las mais ágeis e competitivas, a Emenda Constitucional n 19/98 alterou profundamente alguns conceitos nesta área, em especial que essas empresas e sociedades sujeitam-se ao novo estatuto jurídico, disporá sobre a licitação e contratação de obras, serviços, compras e alienações, sem se desvencilhar dos princípios da administração (art. 173, III, da CF), que são aqueles elencados no caput do art. 37, da Constituição Federal. Sendo que as empresas públicas ${ }^{6}$ e as sociedades de

5 O Decreto-Lei $n^{\circ} 200 / 67$, alterado pela redação do Decreto-Lei $n^{\circ} 900 / 69$, deixou bem claro no art. $5^{\circ}$, incs. Il e III que tanto a Empresa Pública como a Sociedade de Economia Mista são entidades dotadas de personalidade jurídica de direito privado, criadas por lei para a exploração de atividade econômica de interesse estatal.

6 Aprofundar em Caio Tácito, "Regime Jurídico das Empresas Estatais", in RDA 195:1; "Ser- 
economia mista não poderão gozar de privilégios fiscais não extensivos às do setor privado ( $\left(2^{\circ}\right.$, do art. 173 , da $\mathrm{CF}$ ).

Sobre a Emenda Constitucional $n^{\circ} 19 / 98$, deixamos consignado em outra oportunidade ${ }^{7}$ que ela adaptou "o texto Constitucional à realidade econômica das empresas públicas e sociedades de economia mista, excluindo-as do contexto da lei de licitação citada e criando novo ordenamento legal que será baixado, totalmente independente das normas gerais federais vigorantes na matéria".

Nessa vertente, a nova redação conferida ao inc. XXVII do art. 22, da CF, ao eleger que compete privativamente à União legislar sobre normas gerais de licitação e contratação, em todas as modalidades para as administrações públicas diretas, autárquicas e fundacionais da União, Estados e Municípios, destacou que para as empresas públicas e sociedades de economia mista deverão ser obedecidos os precisos termos do art. $173, \S 1^{\circ}$, ou seja, o respectivo estatuto jurídico.

No artigo 175, da CF, fica o Poder Público com a responsabilidade da prestação de serviços diretos, ou sob o regime de concessão ou permissão, precedida do processo licitatório. Além disso, o art. 174 do mesmo Texto Maior dispõe sobre a atuação do Estado "como agente normativo e regulamentador da atividade econômica".

Assim, urge distinguir atividade econômica e o serviço público desempenhado pelo Estado, independentemente da personalidade jurídica eleita pelo Poder Público, pois a empresa estatal que desenvolve atividade econômica em sentido estrito, possui regime próprio das empresas privadas. Nesse caso, as empresas sub oculis possuem direitos patrimoniais disponíveis, condição sine qua non para a utilização da lei de arbitragem.

O STF deixou consignado que é irrelevante a Empresa Estatal (sociedade de economia mista ou empresa pública) possuir a personalidade jurídica de direito privado, pois o que releva necessário perquirir é se ela, nos seus objetivos, se destina à exploração de serviço público ou à consecução da exploração de atividade econômica, para sabermos se estamos diante de direitos patrimoniais disponíveis ou não ${ }^{8}$.

Nesse julgado, o STF analisou a redação inicial do art. $173, \S 1^{\circ}$ da CF, antes da reforma, e seguindo o voto condutor do Min. Relator Celso de Mello, deixou consignado exatamente que :

“...e dizer, as empresas públicas, as sociedades de economia mista e quaisquer outras entidades que explorem atividade econômica, sem monopólio, sujeitam-se à legislação trabalhista das empresas privadas, dada que o fazem em concorrência com estas. Se ocorrem monopólio, não há concorrência ${ }^{9}$."

viços Públicos e Atividades Econômicas na Constituição de 1988", por Roberto Ribeiro Bazili, RDA 197:10).

7 “Licitações e Seus Princípios na Jurisprudência”, ed. Lumen Juris, 1999, p. 206.

8 Cf. Selma M. Ferreira Lernes, “A Arbitragem e os Novos Rumos Empreendidos na Administração Pública - a Empresa Estatal, o Estado e a Concessão de Serviço Público," in "Aspectos Fundamentais da Lei de Arbitragem", ed. Forense, 1999, p. 178. 
A seguir arremata o Eminente Ministro:

"É certo que a empresa pública e sociedades de economia mista são constituídas para a exploração de atividade econômica, em sentido estrito, dado que elas são os instrumentos da intervenção do Estado no domínio econômico. Pode existir, entretanto, empresa pública ou sociedade de economia mista prestadora de serviço público...

$\mathrm{O}$ art. $173, \S 1^{\circ}$, da CF está cuidando da hipótese em que o Estado esteja na condição de agente empresarial, isto é, esteja explorando, diretamente, atividade econômica em concorrência com a iniciativa privada... o que a Constituição quer é que o Estado empresário não tenha privilégios em relação aos particulares. Se houver monopólio não haverá concorrência; não havendo concorrência desaparece a finalidade do disposto no $\S 1^{\circ}$ do art. 173."

O que releva é distinguir no objeto social da empresa paraestatal, a prestação do serviço público do exercício da atividade econômica, campos em tudo diferentes, eis que no primeiro pela supremacia do interesse público o direito é indisponível, enquanto no último pela ausência dessa supremacia, o direito é disponível.

Este divisor de águas se faz necessário, pois partindo da premissa declinada podemos definir que tipo de direito se revela (disponível ou não), para após verificar se pode haver ou não a arbitragem como forma de solução de controvérsia, surgida na execução do contrato firmado com a empresa estatal, pois o artigo $1^{\circ}$ da Lei de Arbitragem elenca os direitos patrimoniais disponíveis como os que poderão valer-se dos dispositivos da Lei $\mathrm{n}^{\circ}$ 9.307, de 23.09.96.

O juízo arbitral, antes da edição da Lei $n^{\circ} 9.307 / 96$, era aplicável em nosso sistema jurídico, pois como já sublinhado no tópico inicial do presente estudo, o Brasil é signatário das regras do Protocolo de Genebra de 1923 e de outros tratados que reconhecem a arbitragem como um dos caminhos a serem perseguidos para a solução de litígios, mesmo que eles envolvam Empresas Estatais.

Exemplo do afirmado, tem-se no julgamento do REsp n $n^{\circ} 616-R J(89.00098535)$, onde a extinta Cia. de Navegação Lloyd Brasileiro se utilizou da arbitragem em contrato internacional, ficando, assim ementado o v. aresto $^{10}$ :

\footnotetext{
“CLÁUSULA DE ARBITRAGEM EM CONTRATO INTERNACIONAL. REGRAS DO PROTOCOLO DE GENEBRA DE 1923.

1 - Nos contratos internacionais submetidos ao Protocolo, a cláusula arbitral prescinde do ato subsequiente do compromisso e, por si só, é apta a instituir o juízo arbitral.
}

9 STF, Adin - MC n $1552-4$, Rel. Min. Celso de Mello, plenário, julgado em 17/04/97, DJ de 7.04.98.

10 STJ, REsp n ${ }^{\circ}$ 616-RJ/89.00098535, Rel. Des. p/ Acórdão, Min. Gueiros Leite, $3^{2}$ T., julgado em $24 / 04 / 90, D J$ de 13.08 .90 . 
2 - Esses contratos têm por fim eliminar as incertezas jurídicas, de modo que os figurantes se submetem, a respeito do direito, pretensão, ação ou exceção, à decisão dos árbitros aplicando-se aos mesmos a regra do art. 244 , do CPC, se a finalidade for atingida.

3 - Recurso conhecido e provido. Decisão por maioria."

A Lei de Licitação (Lei $n^{\circ}$ 8.666/93) também se integra a este quadro, para os contratos administrativos que envolvam financiamentos internacionais, em que é permitida a estipulação da instância arbitral (art. $32, \S 6^{\circ}$ ) como meio legal para a solução de controvérsias surgidas quando do cumprimento e interpretação do contrato.

Seguindo esta nova tendência do direito administrativo, o inc. XVI, do art. 23, da Lei de Concessões (Lei ${ }^{\circ} 8.987 / 95$ ), permite a solução amigável de conflitos ou desavenças verificadas no contrato.

Por fim, concluímos que é plenamente aplicável às empresas públicas e sociedades de economia mista que desenvolvem atividades econômicas em sentido estrito, submetidas aos preceitos jurídicos do direito privado, as regras da arbitragem, desde que conste no contrato firmado cláusula específica ${ }^{11}$ nesse sentido.

\section{IIIb - O Contrato de Concessão e a Lei de Arbitragem}

Ultrapassada a primeira barreira, necessário se faz questionar se lícito seria a solução de uma controvérsia surgida no contrato administrativo de Ministérios ou Autarquias, por meio da arbitragem.

Inicialmente, instado a se pronunciar sobre o presente thema o Tribunal de Contas julgou ser inadmissível o juízo arbitral em contrato administrativo, por falta de autorização legal e ofensa a princípios básicos de direito público, como se verifica na presente ementa ${ }^{12}$ :

" 1 - ... o juízo arbitral é inadmissível em contratos administrativos, por falta de expressa autorização legal e por contrariedade a princípios básicos de direito público (princípio da supremacia do interesse público sobre o privado. princípio da vinculação ao instrumento convocatório da licitação e a respectiva proposta vencedora, entre outros);"

Nessa oportunidade, o TCU frisou o entendimento de que faltava autorização

11 Em igual sentido, radiando brilho, a ilustre Selma M. Ferreira Lernes. ensina: "Verificamos que a Empresa Estatal que desenvolve atividade econômica em sentido estrito se aplicam os preceitos jurídicos do direito privado não estando sujeitas, obrigatoriamente, ao procedimento licitatório, mas a seus princípios. Surge, então. a indagação se poderiam eleger a instância arbitral para solucionar controvérsias oriundas de contratos firmados com particulares". (ob. cit. ant., p. 183).

12 Processo $n^{\circ}$ TC 008.217/93-9, Rel. Min. Homero Santos. Decisão 286/93 - Plenário - Ata 29/93, DOU de 4.08.93, p. 11.192. 
legal, centrando a questão sob o foco que o Decreto-lei $n^{\circ} 2.300 / 86$, em uma única de suas passagens cogita da hipótese de utilização de juízo arbitral em contratos celebrados pela Administração Pública quando o contrato fosse celebrado com a pessoa física ou jurídica domiciliada no estrangeiro (Parágrafo único, do art. 45), ao passo que a Lei $n^{\circ}$ 8.666/93 não repetiu o exato teor do aludido Decreto-Lei revogado, deixando de admitir expressamente até mesmo aquela hipótese de juízo arbitral contemplada anteriormente.

Apesar do Decreto-Lei ${ }^{\circ} 2.300 / 86$ prever o juízo arbitral, admitia como meio idôneo a solver apenas pendências relativas aos contratos administrativos naquelas situações excepcionalíssimas, como já dito, não estendendo seu raio de abrangência para os demais casos.

Todavia, o TCU enalteceu que o novo ordenamento das licitações por ter suprimido expressamente a utilização do juízo arbitral não contemplaria a solução do contrato administrativo pela solução extrajudicial.

A exceção contemplada pela Lei $n^{\circ} 8.666 / 93$ é aquela inerente aos contratos administrativos que envolvam financiamentos internacionais (art. $32, \S 6^{\circ}$ ), onde é permitida a solução de impasses, extrajudicialmente, por meio do julgamento de árbitros.

De outro lado, entendeu também aquela Corte de Contas que a utilização de juízo arbitral em contratos administrativos, afrontaria uma série de princípios de direito público, dentre eles: a) o da supremacia do interesse público sobre o interesse privado; b) o da indisponibilidade de interesse público pela Administração; c) o da inalienabilidade dos direitos concernentes a interesses públicos; d) o do controle administrativo ou tutela; e) o da vinculação do contrato ao instrumento convocatório e à proposta que lhe deu origem.

Posteriormente, após a edição da Lei de Concessões (Lei nº 8.897/95), o Tribunal de Contas da União ${ }^{13}$ reviu o seu entendimento anterior e passou a admitir a inclusão da arbitragem, desde que as cláusulas que sejam julgadas pelos árbitros não ofendam o princípio da legalidade e o da indisponibilidade do interesse público.

Isto porque, o artigo $23, \mathrm{XV}$, da Lei $\mathrm{n}^{\circ} 8.987 / 95^{14}$, elencou como cláusula essencial do contrato de concessão a eleição do foro e o modo de composição amigável.

Comentando esse dispositivo legal, o ilustre mestre Arnoldo Wald ${ }^{15}$, em laço de extrema felicidade sustenta:

13 TCU, Rel. Min. Paulo Affonso Martins de Oliveira, Decisão n 188/65 - Plenário - Ata 18/95, Processo TC $n^{\circ}$ 006.0986/93-2, DOU de 22.5.95, p. 7.277.

14 O professor Marçal Justen Filho, apesar de alertar que há dificuldade na adoção da arbitragem no contrato de concessão, em face da decisão arbitral não podem invadir o interesse público e a auto-executoriedade dos atos administrativos, aduz: “...o contrato poderá determinar a solução amigável de conflitos ou desavenças. A regra remete à matéria da arbitragem. Seria até ideal que os conflitos entre as partes fossem objeto de composição segundo a via de arbitragem." CONCESSÕES DE SERVIÇOS PÚBLICOS - Comentários às Leis nos 8.897 e 9.074, de 1955, ed. Dialética, 1997, p. 272.

15 Arnoldo Wald, "O Direito de Parceria e a Nova Lei de Concessões", ed. RT, 1996, p. 140. 
"11.177 - Está previsto no inc. XV, do art. 23 que o contrato de concessão deve, obrigatoriamente, dispor sobre a forma de composição amigável das divergências contratuais, deixando liberdade de escolha para que a melhor atenda aos interesses em jogo no objeto da concessão.

11.178 - Em complemento a esta disposição, será útil a previsão legal de arbitragem, como instrumento de composição dos conflitos e divergências oriundos do contrato de concessão, entre poder concedente e concessionário, indicados pelas partes os árbitros e as regras a serem observadas.

11.179 - Muito embora não tenha sido expressamente enunciado, pode o contrato estabelecer, como instrumento para viabilizar a composição dos conflitos na aplicação do contrato de concessão, o juízo arbitral, competindo aos árbitros indicados pelas partes, o julgamento extrajudicial da controvérsia. A arbitragem, desde que observadas as prescrições legais civis e processuais, obriga as partes evitando a complexidade e a morosidade do processo judicial. Ao Poder Judiciário compete homologar o laudo arbitral, podendo anulá-lo, se houver sido elaborada em infringência às disposições legais."

Efetivamente, em perfeita sintonia com esse ensinamento o TCU não vê empecilho na aplicação do juízo arbitral ao contrato administrativo de concessão, desde que respeitados os princípios da legalidade e do interesse público.

Apesar de ser um instituto de direito privado, a solução por arbitragem, em alguns casos, por si só, não ofende as regras de direito público, visto que o art. 54, da Lei ${ }^{\circ} 8.666 / 93$, de forma clara, manda aplicar supletivamente os princípios da teoria geral dos contratos e as disposições de direito privado aos contratos administrativos de que trata a aludida lei.

Assim, mesmo o contrato administrativo, que possui feições próprias, exorbitando ao direito comum, pode se utilizar das disposições de direito privado em seus ajustes.

Independentemente da Lei de Arbitragem, o Código Civil em seus arts. 1.025 a 1.036, permite a solução de controvérsias por parte dos próprios interessados de uma relação contratual mediante concessões mútuas, através do juízo arbitral.

Para não pairar dúvida ao intérprete, o Min. Paulo Affonso Martins de Oliveira, ao proferir o seu voto condutor no Processo TC $n^{\circ}$ 006.098/93-2 do TCU, manifestou-se nos seguintes termos:

“Ora, se for admitida a 'transação' como forma de solução de litígios em contratos de concessão, em que o Poder Público e o concessionário fazem 'concessões mútuas' (Código Civil, art. 1.025) para a solução amigável das divergências contratuais, não deve haver qualquer empecilho a que se admita a utilização de árbitros.

A interpretação teleológica do Art. 23 , inciso XV, da Lei $n^{\circ} 8.987 / 95$ teve concluir que o legislador utilizou a expressão 'modo amigável de solução de divergências' em oposição a 'solução jurisdicional de controvérsias. 
A utilização da arbitragem encontra, portanto, fundamento legal, sendo descabido falar-se em violação do princípio da legalidade, e constitui forma célere e econômica para a solução de litígios em contratos de concessão, podendo apenas trazer vantagens para a Administração Pública.

Deve-se concluir, portanto, que a utilização de árbitros possui amparo legal (Lei 8.987/95) e apresenta-se conveniente para a Administração Pública, não sendo mais possível após o advento da legislação mencionada, falar-se em ilicitude da cláusula do Contrato de Concessão celebrado..."

Portanto, apesar da relação contratual com o Poder Público ser regida pelo Direito Público, o legislador infraconstitucional permite que no contrato de concessão se inclua nas suas cláusulas a solução amigável de possíveis controvérsias.

Resta aferir se esta solução fere alguns dos princípios do direito público e que foram objeto da primeira análise do TCU (Processo TCU $n^{\circ} 008.217 / 93-9$ ) onde aquela Col. Corte de Contas vedou a solução arbitral em contrato administrativo, por entender que seriam violados os preceitos que se seguem:

A Supremacia do Interesse Público sobre o Interesse Privado. O princípio em voga não se configura como totalitário ou abusivo, eis que o interesse público é aquele se coaduna com a vontade coletiva, em oposição a entendimento ou vontade pessoal do agente público. O moderno direito administrativo penetra na essência do posicionamento adotado pelo Estado, para aferir se há razoabilidade entre o fim que vai atingir e o dano que vai causar.

Tivemos a oportunidade de enfrentar este tema, com maior profundidade em nosso "Licitação e seus Princípios na Jurisprudência ${ }^{16 ", ~ o n d e ~ s u b l i n h a m o s ~ q u e: ~}$ "Mais significativamente, o Estado Moderno se adapta política e economicamente ao bem-estar social (Wellfare State), tendo o administrado hipossuficiente na relação com o ente público, proteção capaz de manter o verdadeiro equilíbrio, visto que o Estado não pode marchar para o totalitarismo, por ser figura oposta ao princípio democrático de direito reinante no Texto Constitucional ${ }^{17}$."

Entendemos que o julgamento pelo juízo arbitral de cláusula de Contrato de Concessão, não fere o princípio da Supremacia do Interesse Publico, visto que a autoridade pública ao invés de ser julgada pelo órgão do Poder Judiciário será julgado por árbitros que seguirão regras pré-estabelecidas, sendo que uma delas é a que eles não poderão divorciar dos seus entendimentos os princípios contidos no caput do art. $37 \mathrm{da} \mathrm{CF}$.

Assim, o Interesse Público será preservado quando for verificado que a voz do Poder Público se encaixa no real interesse da coletividade e não em uma mera fachada de interesses pessoais dos homens públicos, que ao talante do aludido princípio, subvertem o seu real valor para desviar-se dos objetivos traçados no próprio contrato administrativo, cometendo excesso de poder.

16 Ob. cit., ed. Lumen Juris, 1999, p. 76.

17 Aprofundar em "Temas de Direito Público (Estudos e Pareceres), in "Do Estado Liberal ao Bem-estar Social", 1 vol., 1997, ed. Renovar, p. 381. 
Indisponibilidade do Interesse Público pela Administração. O julgamento pelo sistema da arbitragem, por óbvio respeitará a figura do interesse público. Todavia, por ser eleita a aludida fórmula de composição amigável não serão feitas concessões amplas, gerais e irrestritas pela Administração, apenas ela se submeterá ao julgamento extrajudicial, que como já dito anteriormente será ultimado levando em consideração as regras de direito público que são irrenunciáveis.

Inalienabilidade dos Direitos Concernentes a Interesses Públicos. Não seria ferida a inalienabilidade dos direitos concernentes a interesses públicos porque as cláusulas exorbitantes do Contrato Administrativo não podem ser alteradas pelo juízo arbitral, por serem princípios de ordem pública. A utilização da arbitragem para dirimir contenda resultante em um contrato público possui barreiras que não poderão ser penetradas, e uma delas é a revogação das cláusulas especiais (exorbitantes) colocadas a efeito para preservar o interesse da coletividade.

Do Controle Administrativo ou Tutela. Por igual, o juízo arbitral não invade o princípio do controle administrativo ou tutela, pois se a administração não revê seus atos atinentes à contratação que causem lesão ao particular contratado este não necessitará aguardar uma eternidade para esperar a boa vontade do ente público. Assim, o controle interno feito pelo próprio órgão ou ente de direito público possui um limite, que é o bom senso agregado ao tempo de espera, que se não forem implementados pela Administração abre as portas para o litígio que poderá ser judicial ou extrajudicial, sendo que este último, com algumas ressalvas que serão expostas mais a frente.

A Vinculação do Contrato ao Instrumento Convocatório e à Proposta que lhe deu Origem. O Juízo arbitral não será convocado para alterar a proposta que deu origem a vitória do certame licitatório, e por esta razão não invadirá a vinculação do contrato ao instrumento convocatório.

Atuará o Tribunal Arbitral em sintonia com a estabilidade das regras e condições que precederam o processo licitatório, bem assim das condições ofertadas na proposta vencedora do mesmo certame.

Posto sob censura os princípios de direito público que foram utilizados inicialmente pelo TCU (Processo $n^{\circ}$ TC 008.217/93-9) para negar a utilização do juízo arbitral, se constata que não são mitos e que não são violados quando a Lei de Concessões permite ao contrato administrativo incluir em suas cláusulas a solução pela via amigável.

A propósito, cabe citar importante julgado do Supremo Tribunal Federal ${ }^{18}$ que em sessão plenária realizada em 1973, seguindo posicionamentos anteriores prestigiou o juízo arbitral nas relações privadas do Estado:

18 STF, AI n 52.181 - Guanabara, Rel. Min. Bilac Pinto, Pleno, Julgado em 14.11.73, DO de 13.02.74, in RTJ 68/382. 
"INCORPORAÇÃO - BENS E DIREITOS DAS EMPRESAS ORGANIZAÇÃO LAGE E DO ESPÓLIO DE HENRIQUE LAGE - JUÍZO ARBITRAL - CLÁUSULA DE IRRECORRIBILIDADE - JUROS DE MORA - CORREÇÃO MONETÁRIA.

1 - Legalidade do Juízo Arbitral, que o nosso Direito sempre admitiu e consagrou, até mesmo nas causas contra a Fazenda. Precedente do Supremo Tribunal Federal.

2 - Legitimidade da cláusula de irrecorribilidade de sentença arbitral, que não ofende a norma constitucional.

5 - Agravo de Instrumento a que se negou provimento."

Nesse expressivo julgado, o eminente Min. Bilac Pinto, cita o voto do Ministro Godoy Ilha, do Tribunal Federal de Recursos, que deixou assente nos anais daquela Corte, que:

“(...) Juízo Arbitral - Na tradição do nosso direito o instituto do Juízo Arbitral sempre foi admitido e consagrado, até mesmo nas causas contra a Fazenda. Pensar de modo contrário é restringir a autonomia contratual do Estado, que, como toda pessoa sui juris poder prevenir o litígio pela via do pacto de compromisso, salvo nas relações em que age como Poder Público, por insuscetíveis de transação.

Natureza consensual do pacto de compromisso - O pacto de compromisso, sendo de natureza puramente consensual, não constitui foro privilegiado nem tribunal de exceção, ainda que regulado por lei específica.

Princípios de instituto jurídico - Os princípios informativos de um instituto jurídico de direito privado podem ser modificados ou até mesmo postergados por norma legal posterior.

Cláusula de Irrecorribilidade - A cláusula de irrecorribilidade de sentença arbitral é perfeitamente legítima e não atenta contra nenhum preceito da Carta Magna, sendo também dispensável a homologação judicial dessa sentença, desde que, na sua execução, seja o Poder Judiciário convocado a se pronunciar, dando assim, homologação tácita ao decidido".

Por certo, que o Estado possui uma margem razoável de autonomia contratual que, como toda a pessoa sui juris, pode prevenir o litígio pela via transacional, não sendo lícito restringir esse direito ao Poder Público, que pode transigir na jurisdição paralela à da justiça ordinária e através da arbitragem resolver controvérsias que não invadam princípios constitucionais e administrativos indelegáveis.

Ou seja, o Poder Público pode se socorrer do caráter consensual do compromisso arbitral, desde que as cláusulas objeto da disputa demonstrem ser oriundas de direitos disponíveis, não incidindo sobre interesse público, que é indisponível por não se achar entregue a livre disposição do administrador.

Aliás, o nosso entendimento vem coroado pelo pensamento também do TCU, que ao proferir magnífico posicionamento na citada decisão $n^{\circ} 180 / 95$ (Processo $n^{\circ}$ 
TC 006.098/93-2), deixou averbado que não se deve incluir, na parte da arbitragem, cláusulas que não observem estritamente os princípios da legalidade e da indisponibilidade do interesse público, tendo em vista que estes princípios não pertencem aos. direitos disponíveis e, por consequiência, ficam fora do Juízo Arbitral.

É de se abrir parênteses para registrar a autorizada visão do Min. Revisor do aludido processo TCU n 006.098/93-2, Min. Carlos Átila Alvares da Silva:

“...ressalvando somente que o DNER deve cuidar de não incluir, na parte da arbitragem, cláusulas que não observem estritamente os princípios da legalidade e da indisponibilidade do interesse público (...) o juízo arbitral terá sempre de conformar-se àqueles princípios fundamentais, e por isso e enfatizo este ponto - sempre que o laudo contrariar tais princípios, o responsável pelo órgão público contratante fica obrigado a recorrer à Justiça contra o laudo.

Assim entendida a questão, penso que efetivamente se pode aceitar que a Lei $\mathrm{n}^{\circ} 8.987 / 95$ tenha vindo inovar na matéria - e só assim se pode interpretá-la, sob pena de inconstitucionalidade."

Dentro da sua faixa de discricionariedade, sem se desprender dos princípios cardeais do direito administrativo (art. 37, da CF), poderá a Administração eleger o compromisso arbitral para resolver pendências na execução de cláusulas contratuais que não invadam o princípio da legalidade, ao qual está o gestor público ininterruptamente submetido, inclusive quando aceita o compromisso de arbitramento.

O que não é justo é engessar o Poder Público negando a sua autonomia contratual das cláusulas inerentes aos direitos disponíveis. Com toda a certeza é legítima a opção pela jurisdição paralela à da justiça ordinária.

IV - Vantagens da arbitragem e situações em que ela pode ser efetivada ou não

Clóvis Beviláqua ${ }^{19}$, autor do Código Civil, define o instituto da arbitragem como:

“(...) ato jurídico, pelo qual as partes, fazendo-se concessões recíprocas, extinguem obrigações litigiosas ou duvidosas. Pressupõe dúvida ou litígio a respeito da relação jurídica."

E Castro Nunes, invocado por Bilac Pinto no AG. $\mathrm{n}^{\circ}$ 52.181-GB/STF, deixou consignado em laborioso parecer, a seguinte característica do juízo arbitral:

“O que se assegura é o direito à jurisdição, o acesso às justiças regulares,

19 Clóvis Beviláqua, "Código Civil dos Estados Unidos do Brasil", vol. IV, $11^{2} \mathrm{ed}$., ed. atualizada por Achilles Beviláqua, Paulo de Azevedo Lida., 1958, p. 142. 
a possibilidade ressalvada de poderem levar à Juízo a sua pretensão ou de não responderem senão em Juízo. Ao inverso, o Juízo Arbitral supõe, no ato da sua Constituição, o acordo das partes que consentem em subtrair a causa às Justiças regulares, estando pelo que decidirem os Juízes-árbitros por eles escolhidos. Jamais se estendeu, aqui o alhures, pudesse o compromisso arbitral constituir uma infração daquele princípio tradicional uma autorização legislativa para a instituição do Juízo Arbitral, e, em tal caso, provindo da lei, como sucede na hipótese, a subtração do litígio às justiças regulares. Mas, o compromisso firmado com a outra parte importaria na aceitação por esta via adotada em substituição à judiciária, conservando-se assim no plano consensual a solução arbitral."

Feito este breve relato, se verifica que o Juízo Arbitral garante algumas vantagens para as partes, visto que pelo princípio da continuidade do serviço público, qualquer contenda que envolva direitos disponíveis na execução do contrato administrativo terá uma maior celeridade pela decisão arbitral.

A rapidez da solução da arbitragem é justificada pela falta de acúmulo de processos com que são envolvidos os Juízes de direito, que a cada dia que passa recebem verdadeira avalanche de feitos novos. Já o Juízo Arbitral possui a característica da exclusividade, ou seja, os árbitros são escolhidos para solucionarem aquela demanda, o que farão em tempo bem inferior, aquele gasto na Jurisdição Ordinária.

Outra vantagem para a Administração Pública é o custo inferior, ou seja, pela arbitragem o Poder Público despende valor bem inferior do que se sucumbente no Judiciário.

Não resta dúvida de que estes ingredientes - celeridade e economicidade são suficientes para prestigiarem o instituto da arbitragem nos direitos disponíveis do Poder Público, onde ele pode transigir a solução pela via da negociação.

Os direitos privativos (indisponíveis) do Estado são irrenunciáveis e não podem ser objeto de transação, salvo se por expressa autorização legislativa onde se demonstre o interesse público.

Nessa vertente, a questão fundamental está alçada em diferenciar entre o que pode ser objeto de decisão arbitral e o que não pode ser. Para isso é necessário uma discriminação dos atos administrativos de autoridade (latu sensu) que são baixados sob a couraça do interesse público, onde a indisponibilidade é a marca de atuação do homem público.

$\mathrm{O}$ art. 55, da Lei $\mathrm{n}^{\circ} 8.666 / 93$ estipula as cláusulas necessárias ${ }^{20} \mathrm{em}$ todo o contrato administrativo e o art. 23, da Lei $n^{\circ} 8.989 / 95$ elenca as cláusulas essenciais do Contrato de Concessão Pública, que deverão guardar perfeita sintonia com o edital e a proposta vencedora, já que consolidará os direitos e obrigações assumidos pelos contraentes.

20 "É obrigatória a inclusão, nos contratos, de todas as cláusulas necessárias, nos termos definidos na Lei 8.666/93”. (TCU - Decisão n 112/96, DOU de 26 de março de 1996, p. 5.026. 
Por serem necessárias, elas não poderão ser analisadas pelo Juízo Arbitral, que estaria invadindo direito indisponível, defeso pelo próprio art. $1^{\circ}$, da Lei $n^{\circ} 9.307 / 96$.

Igualmente, a tarifa do serviço público concedido, fixada pelo preço da proposta vencedora da licitação, que é reajustada e revista pelas regras contidas na Lei ${ }^{\circ}$ $8.987 / 95$, no edital e no respectivo contrato não poderá sofrer modificação pelo juízo arbitral, que invadiria a competência que não lhe é outorgada por lei (direito disponível).

Caso ocorra desrespeito ao equilíbrio econômico-financeiro do contrato, e que consiste na real e efetiva manutenção do poder aquisitivo da tarifa proposta e ajustada no compromisso firmado entre particular e poder concedente, deverá a parte lesada ou prejudicada (contratado) se socorrer do manto protetor do Poder Judiciário, pois apesar de ser direito cristalino e insofismável tal equilibrio, o poder público não possui procuração para acordar sobre tais desequilibrios, a não ser que eles estejam invencivelmente comprovados, sendo incontroversa a adulteração da proposta inicial.

Por igual, as cláusulas exorbitantes (exorbitam o direito privado) também não poderão ser objeto de apreciação do Juízo arbitral, por serem fixados para a preservação do interesse público. São elas: a) modificação unilateral para melhor adequação às finalidades de interesse público, respeitados os direitos dos contratados; b) rescisão unilateral, nos casos especificados no inciso I, do art. 79, da Lei $\mathrm{n}^{\circ}$ 8.666/93; c) fiscalização da execução do contrato; d) aplicação de sanções motivadas pela inexecução total ou parcial do ajuste e; e) nos casos de serviços essenciais, ocupar provisoriamente bens móveis, imóveis, pessoal e serviços vinculados ao objeto do contrato, na hipótese de graves faltas contratuais.

Todavia, se a administração pública desejar alterar as cláusulas econômico-financeiras e monetárias do contrato administrativo, dependerá da prévia concordância do contratado (art. $58, \S 1^{\circ}$, da Lei ${ }^{\circ} 8.666 / 93$ ) sem a qual não poderá ser implementada nenhuma mudança da metodologia genesis do ajuste.

Como quem cederá é o particular, caso concorde com as postulações do poder público, poderá esta composição ser feita através do Juízo Arbitral, por tratar-se de direito disponível do contratado.

Também é lícita a solução arbitral quando ocorrerem as hipótese de alteração dos contratos por acordo das partes, consoante o art. 65, II, da Lei ${ }^{\circ} 8.666 / 93$ :

Art. 65 - Os contratos regidos por esta Lei poderão ser alterados, com as devidas justificativas, no seguintes casos:

II - Por acordo das partes;

a) quando conveniente a substituição da garantia de execução;

b) quando necessária a modificação do regime de execução da obra ou serviço, bem como do modo de fornecimento, em face de verificação técnica da inaplicabilidade nos termos contratuais originários;

c) quando necessária a modificação da forma de pagamento, por imposição de circunstâncias supervenientes, mantido o valor inicial atualizado, vedada a antecipação do pagamento, com relação ao cronograma financeiro fixado, sem a correspondente contraprestação de fornecimento de bens ou execução da obra ou serviço; 
d) para restabelecer a relação que as partes pactuaram inicialmente entre os cargos do contrato e a retribuição da Administração para a justa remuneração da obra, serviço ou fornecimento, objetivando a manutenção do equilibrio econômico-financeiro inicial do contrato, na hipótese de sobrevirem fatos imprevisíveis, ou previsíveis, porém de consequiências incalculáveis, retardadores ou impeditivos da execução do ajustado, ou ainda, em caso de força maior, caso fortuito ou fato do príncipe, configurando álea econômica extraordinária e extracontratual."

Poderá haver também juízo arbitral para a solução dos contratos dos entes públicos que tenham a característica privada $\left(\S 3^{\circ}\right.$, do art. 62 , da Lei $\left.n^{\circ} 8.666 / 93\right)$, tais como: contratos de seguro, financiamento, de locação, e etc.

Em resumo: todas as cláusulas que impliquem em remissão, transação ou renúncia de direitos de conteúdo público, como as relativas ao exercício do poder de polícia, do poder impositivo, das bases das tarifas, da disposição do domínio público, de controlar a prestação dos serviços concedidos não são admitidos no Juízo Arbitral, por serem enquadrados como direitos indisponíveis e como tal insuscetível da solução extrajudicial.

Podem submeter-se às decisões arbitrais as matérias de índole privada, ou aquelas narradas nos exemplos anteriores, onde a interpretação de determinadas cláusulas contratuais não ofendem a indisponibilidade do interesse público.

\section{Conclusão}

A evolução dos tempos também faz eco no direito público, onde a arbitragem permite que em determinados casos - em especial aos que envolvem direitos disponíveis - possa haver composição, via juízo arbitral, entre o poder público e o ente privado.

O cenário atual consagra esta tendência, em muito reforçada pela Lei Federal $\mathrm{n}^{\circ} 8.987 / 95$, cujo artigo $23, \mathrm{XV}$, define como cláusula essencial no Contrato de Concessão e Permissão de Serviços, aquela que elege o caminho da composição amigável, como via obrigatória para dirimir conflitos e controvérsias.

Assim nasceu a nova oportunidade do Poder Público e o particular resolverem as suas desavenças na execução ou cumprimento do contrato administrativo através de um julgamento consensual, via juízo arbitral, nos casos declinados alhures e que correspondam a direitos disponíveis, sem que haja choque com o princípio da legalidade e o interesse público. 


\section{Proteção ao Processo}

\section{Rosana Josefa Martins Dias}

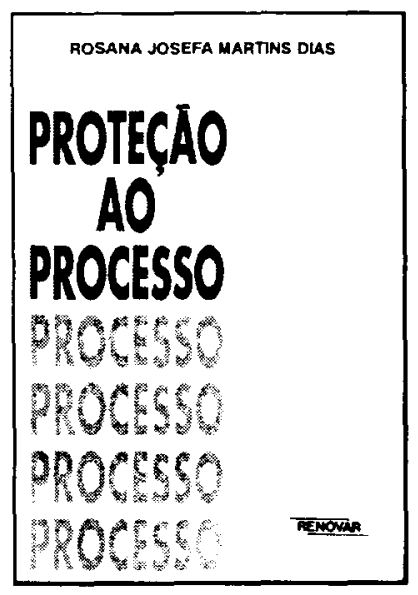

Este livro é um estudo sistematizado sobre os mecanismos de proteção ao processo, tendentes a preservar a utilidade da prestaçāo jurisprudencial bem como a resguardar os valores intrínsecos do precioso instrumento estatal, colocado à disposição dos individuos para o deslinde de seus conflitos de interesse.

Ref. 0066

Form. 14x21
Brochura

1994
155 págs.

\section{Questões Controvertidas de Locação e Condomínio}

Este livro reúne algumas das diversas publicações de artigos jurídicos de autoria do advogado Geraldo Beire Simöes, especializado em Direito Imobiliário, em vários órgãos de divulgação, versando sobre variadas questões controvertidas de locação, principalmente, e condominiais, além de trabalhos sobre a recente reforma do CPC e questões diversas.

Ref. 0128

Form. 14x21
Brochura 1997
Geraldo Beire Simões

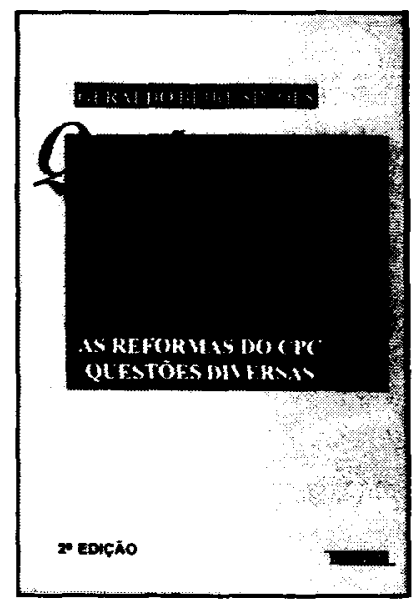

